\title{
Review of Microstrip Patch Antenna Array at 6GHz Frequency for Long Term Evolution Applications
}

\author{
Samreen Aftab \\ M.Tech Scholar \\ Department of Electronics and Communication Engineering \\ Sagar Institute of Science and Technology, Bhopal, India
}

\author{
Prof. Mohd Abdullah \\ Associate Professor \\ Department of Electronics and Communication Engineering \\ Sagar Institute of Science and Technology, Bhopal, India
}

\begin{abstract}
An antenna is the interface between radio waves spreading through space and electric flows moving in metal conduits, utilized with a transmitter or collector. In transmission, a radio transmitter supplies an electric flow to the antenna's terminals, and the antenna emanates the vitality from the flow as electromagnetic waves (radio waves). A portion of the hopeful groups for $5 \mathrm{G}$ interchanges in the frequency of $4-8 \mathrm{GHz}$ at lower range and $20-50 \mathrm{GHz}$ are in upper range. It is normal that the sending of $5 \mathrm{G}$ would be in the right on time of 2020s. In this paper review of microstrip patch antenna array at $6 \mathrm{GHz}$ frequency for long term evolution applications are studied. Microstrip patch antenna array are now very hot topic of research among various researchers.
\end{abstract}

Keywords- Microstrip, patch, antenna, array, $6 \mathrm{GHz}$

$* * * * *$

\section{INTRODUCTION}

Ordinary 4G innovation utilizes frequency band of $2-8 \mathrm{GHz}$ giving a transfer speed of $5-20 \mathrm{MHz}$ be that as it may, these days as IoT is getting to be well known, client transmission capacity prerequisite has expanded. To help this expansive information traffic $5 \mathrm{G}$ is the most recent conceivable arrangement. For $5 \mathrm{G}$, frequencies of around $50 \mathrm{GHz}$ are being considered and this will display some genuine difficulties as far as the circuit plan. 5G antennas are required to be littler, high-gain frameworks than those that have served $3 \mathrm{G}$ and $4 \mathrm{G}$ frameworks, and they will require further developed directing and filtering systems so as to work well at millimeter wave frequencies. Utilizing frequencies a lot higher in the frequency range gives the likelihood of having more extensive channel transfer speed conceivably $1-2 \mathrm{GHz}$. Be that as it may, this stances new difficulties for handset improvement where most extreme frequencies of around $2 \mathrm{GHz}$ and transmission capacities of $10-20 \mathrm{MHz}$ are right now being used. Late works shows to demonstrate that a four-component double band printed space antenna cluster for 5G mobile correspondence systems give great impedance coordinating at the ideal frequency groups of $28 / 38 \mathrm{GHz}$ for $|\mathrm{S} 11|$ under -10 $\mathrm{dB}$, with a gain of $10.58 \mathrm{dBi}$ at $28 \mathrm{GHz}$ and $12.15 \mathrm{dBi}$ at 38 GHz. An antenna with high gain and pillar steerable can be intended for $5 \mathrm{G}$ cell handset gadgets. Some ongoing deals with high gain and bar guiding have been distributed in most recent couple of years. A minimized T-molded opened small scale strip patch antenna can give reflection coefficient beneath $-10 \mathrm{~dB}$ from $55.80 \mathrm{GHz}$ to $67 \mathrm{GHz}$. The gain of antenna is $6.34 \mathrm{~dB}$. This proposed $5 \mathrm{G}$ antenna, $5 \mathrm{G}$ framework works at $33.5 \mathrm{GHz}$ gain is around $9 \mathrm{dBi}$ which is more and less return loss about $-29 \mathrm{~dB}$ is alluded from above writing works. The working frequency is on $33.5 \mathrm{GHz}$ which makes this antenna progressively efficient for the mobile administrators to set up $5 \mathrm{G}$ framework.

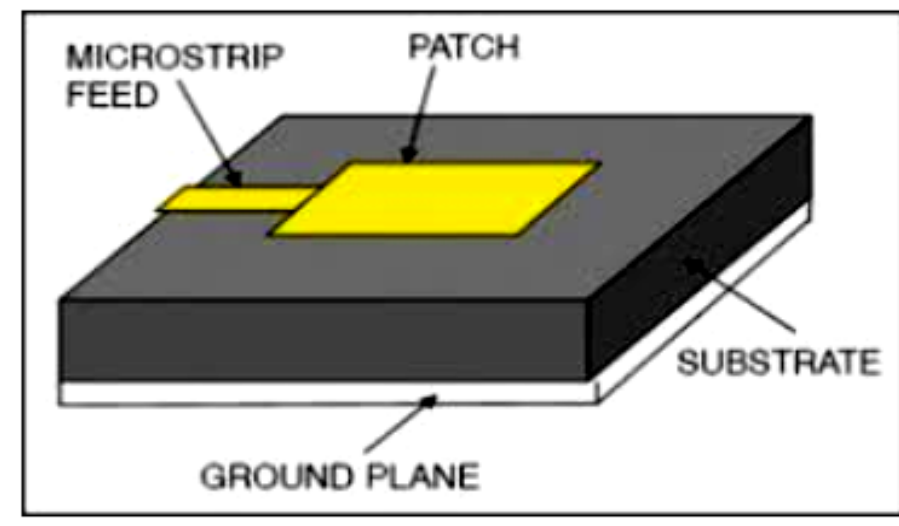

Figure 1: Microstrip Antenna

\section{LITERATURE REVIEW}

A. N'Gom et al., [1] This work presents the design of an adaptive subarray antenna for multi-beams wireless small cell array backhaul in mmWave (above 6GHz). This structure consists of $2 \times 2$ dual polarized driven cross patch each has surrounded by four parasitic elements that can be connected if necessary to the ground plane by a pin to act as directors/reflectors to the ground plane to act as directors/reflectors. The proposed structure excited by 4 Wilkinson dividers power feeding system can generate three high gain beam patterns with $3 \mathrm{~dB}$ total beam-width of $153^{\circ}$ with a maximum total gain around $10 \mathrm{dBi}$ at frequency $10.4 \mathrm{GHz}$ in each orthogonal plane, following a combination of 
the ports to be excited and the location of the short-circuit on the parasitic elements surrounding the radiating elements. To validate the concept, a prototype is fabricated and an excellent agreement is obtained between the simulation and experimental results in terms of the return loss, isolation and the radiation pattern of the planar subarray antennas.

J. Lin, et al., [2] This work proposed a novel dual-band magnetoelectric dipole end-fire antenna. The proposed antenna is composed of a self-complementary bow-tie structure with a triangular patch and a triangular slot as electric dipole on both sides of the substrate, a co-excited quarter-loop that operates as magnetic dipole, a vertical ground plane, and a microstrip transition balun. The proposed antenna achieves a dual-band operation at $2.2 \sim 2.6 \mathrm{GHz}$ for WLAN and $1.15 \sim 1.25 \mathrm{GHz}$ for telemetry L-band, respectively, with the highest gain of approximately $10 \mathrm{dBi}$ and an average gain of $7 \mathrm{dBi}$ during the whole operating bandwidth with an excellent front to back ratio of $26.5 \mathrm{~dB}$. Meanwhile, the stable unidirectional radiation patterns and low back lobe are also obtained during the dual bands.

Y. N. Wijayanto et al., [3] it is propose and report W-band millimeter-wave patch antennas on an optical modulator for foreign object debris (FOD) detection to support runway security systems. The proposed device can be used for receiving wireless millimeter-wave signals and converting to lightwave signals trough optical fiber networks for distribution. In experiment, the proposed device was fabricated successfully in an array structure. In measurement, about $40 \mathrm{~dB}$ optical sidebands to carrier ratio was obtained. Approximately $6 \mathrm{GHz}$ bandwidth was also obtained using the fabricated devices.

M. Sugadev et al., [4] In this work, analysis of a compact triple band microstrip antenna based on principle of etching slots in the radiating patch to produce desired resonance frequency is discussed. The proposed triband microstrip patch antenna achieved resonances at $3.6 \mathrm{GHz}, 5.6 \mathrm{GHz}$ and $7.9 \mathrm{GHz}$. The miniaturization of the designed triband microstrip antenna is achieved with the introduction of slots in the radiating patch as well as the ground plane, which helps in notching the unwanted bands. In this antenna, two L-shaped slots and a modified M-shaped slot is introduced in the radiating patch. In addition to this two more slots are etched in the ground layer to achieve resonance at required application frequencies. A $50 \Omega$ impedance transmission line is introduced in the structure for achieving proper impedance matching. FR4 epoxy resin is used for the substrate because of its rigid structure and lossy nature which enhances radiation effects. The proposed antenna achieved a return loss of less of $-10 \mathrm{~dB}$ at resonant frequencies of $3.5 \mathrm{GHz}, 5.5 \mathrm{GHz}$ and $7.5 \mathrm{GHz}$ both in simulation and measured results. The measured VSWR of the proposed antenna is below 2 and the gain is $0.826 \mathrm{~dB}$.

A. Abdellatif, et al., [5] This work presents a low cost high gain patch antenna array for automotive radar applications. A compact wide band $(9.6 \mathrm{GHz})$ low loss $(0.5 \mathrm{~dB}$ at $79 \mathrm{GHz})$ micro-strip line to waveguide transition is also proposed for the antenna testing. The proposed antenna has a measured gain of $14.5 \mathrm{dBi}$ at $79 \mathrm{GHz}$. The proposed antenna (including the transition) has been fabricated using a single dielectric layer PCB process with a total length of $35 \mathrm{~m}$

Bin Lu et al., [6] A microstrip line-fed patch antenna array is developed based on a novel PCB/epoxy/polypropylene/epoxy composite substrate for $60-\mathrm{GHz}$ WPAN applications. The substrate features high RF performance as PTFE or LTCC, while the cost and manufacturing complexity is much lower than the above two materials, and therefore provides a great convenience for the integration of antennas with a transceiver front-end at $60-\mathrm{GHz}$ band. This work introduces the fabrication process of the substrate in detail, and the $2 \times 2$ and $4 \times 4$ demo patch antenna arrays fabricated on the substrate are developed. Measurement results showed that the peak gains of the two antenna arrays are $11.7 \mathrm{dBi}$ and $15.4 \mathrm{dBi}$, respectively, while the bandwidth is at least $5.6 \mathrm{GHz}$, which agree well with the simulation results.

R. J. Chitra, et al., [7] In this work, a double L-slot microstrip patch antenna array using an infinite ground plane and step width junction-feed for Worldwide Interoperability for Microwave Access (WiMAX) and Wireless Local Area Network (WLAN) applications were presented. The proposed microstrip patch antenna array consists of two rectangular patch element embedded with two $\mathrm{L}$ shaped slot with a compact size of $30.65 \mathrm{~mm} \times 36.35 \mathrm{~mm} \times 1 \mathrm{~mm}$. The proposed antenna was analyzed with two different feed arrangements and operates at $3.6 \mathrm{GHz}$ to cover the frequency bands of WLAN (2.4 to $5.8 \mathrm{GHz})$ and WiMAX (2.5 to $5.5 \mathrm{GHz})$ and satisfying the antenna requirements using Ansoft (HFSS). Antenna parameters such as return loss, VSWR, impedance matching and radiation pattern were analyzed. Simulated results for the designs are studied and investigated.

S. Muhamud, et al., [8] This work presents a study on a microstrip antenna with slotted patch at different slot orientations. The proposed antenna was designed using FR-4 substrate based on aperture coupler technique. A rectangular slot was inserted on to the radiating patch in two different types of orientation, horizontal and vertical in order to operate at a different frequency at a time. CST Microwave Studio Suite 2009 software has been used to simulate the design at operating frequency range of $2-6 \mathrm{GHz}$. A comprehensive parametric study was done to understand the effects of changing the slot dimensions and the axis spacing towards antenna performance while maintaining the patch size. The simulation results were analyzed and presented in terms of return loss, voltage standing wave ratio (VSWR) and radiation patterns. The proposed antenna is able to operate at three different operating frequencies of $2.4 \mathrm{GHz}, 4.6 \mathrm{GHz}$ and $5.7 \mathrm{GHz}$ without changing the patch dimensions. This design 
concept can be useful in designing an array antenna with frequency reconfigurability.

Table 1: Summary of Literature Review

\begin{tabular}{|c|c|c|c|c|c|c|}
\hline $\begin{array}{c}\text { Sr } \\
\text { No. }\end{array}$ & $\begin{array}{l}\text { Auth } \\
\text { or } \\
\text { Nam } \\
\text { e }\end{array}$ & $\begin{array}{c}\text { Year of } \\
\text { Publica } \\
\text { tion }\end{array}$ & $\begin{array}{l}\text { Frequ } \\
\text { ency } \\
\text { Rang } \\
\text { e }\end{array}$ & $\begin{array}{l}\text { Multi- } \\
\text { band }\end{array}$ & $\begin{array}{c}\text { Feedi } \\
\text { ng } \\
\text { Point }\end{array}$ & Objective \\
\hline 1 & Y. Li & $\begin{array}{l}\text { June } \\
2018\end{array}$ & $\begin{array}{c}3.4- \\
5.9 \\
\mathrm{GHz}\end{array}$ & $\begin{array}{c}\text { Single } \\
\text { Band }\end{array}$ & 1 & $\begin{array}{c}\text { Eight-element } \\
\text { multiple-input } \\
\text { multiple- } \\
\text { output } \\
\text { (MIMO) } \\
\text { antenna }\end{array}$ \\
\hline 2 & $\begin{array}{l}\text { S. N. } \\
\text { M. } \\
\text { Zaina } \\
\text { rry }\end{array}$ & $\begin{array}{l}\text { Nov } \\
2017\end{array}$ & $\begin{array}{c}3-4 \\
\mathrm{GHz}\end{array}$ & $\begin{array}{c}\text { Single } \\
\text { Band }\end{array}$ & 1 & $\begin{array}{c}\text { Antennas } \\
\text { exhibit wide } \\
\text { bandwidth } \\
\text { above } 4 \mathrm{GHz} \\
\text { with an } \\
\text { average gain } \\
\text { values more } \\
\text { than } 12.5 \mathrm{dBi} \text {. }\end{array}$ \\
\hline 3 & $\begin{array}{c}\text { J. } \\
\text { Zeng }\end{array}$ & $\begin{array}{c}\text { Sep } \\
2016\end{array}$ & $\begin{array}{l}2.6- \\
\mathrm{GHz}\end{array}$ & $\begin{array}{c}\text { Single } \\
\text { Band }\end{array}$ & 1 & $\begin{array}{c}\text { Hybrid } \\
\text { antenna array } \\
\text { elements are } \\
\text { symmetrically } \\
\text { placed along } \\
\text { the long edges }\end{array}$ \\
\hline 4 & $\begin{array}{c}\text { S. } \\
\text { Kum } \\
\text { ar }\end{array}$ & $\begin{array}{c}\text { Oct } \\
2018\end{array}$ & $\begin{array}{c}3.4- \\
5.9 \\
\mathrm{GHz}\end{array}$ & $\begin{array}{c}\text { Single } \\
\text { Band }\end{array}$ & 1 & $\begin{array}{c}\text { Proposed } \\
\text { MIMO } \\
\text { antenna is } \\
\text { composed of } \\
\text { three different } \\
\text { antenna } \\
\text { element types }\end{array}$ \\
\hline 5 & $\begin{array}{c}\text { I. } \\
\text { Acha } \\
\text { rya }\end{array}$ & $\begin{array}{c}\text { Mar } \\
2018\end{array}$ & $\begin{array}{c}3.4- \\
3.6 \mathrm{G} \\
\mathrm{Hz}\end{array}$ & $\begin{array}{c}\text { Single } \\
\text { Band }\end{array}$ & 1 & $\begin{array}{l}2 \times 2 \text { microstri } \\
\text { p patch array } \\
\text { antenna for } \\
5 \mathrm{G}\end{array}$ \\
\hline
\end{tabular}

\section{ANALYSIS METHODS}

Analysis strategies for the microstrip antenna can essentially be separated into two gatherings; techniques that depend on the equal attractive flow circulation around the patch edges and furthermore strategies that depend on the electric flow dissemination on the patch conduit and the ground plane. For this sort of examination techniques, the radiation from the microstrip antenna is determined from the proportional attractive current appropriation around the fringe of the transmitting patch, which is gotten from the comparing voltage conveyance. Means the investigation issue is focused on finding the edge voltage appropriation for a given excitation and for a predetermined mode. Two principle techniques dependent on this sort of investigation are transmission line show and the pit display. For the electric flow conveyance based technique, the Strategy for Minutes (Mother) is the most widely recognized. This strategy is considered as a full wave show which incorporates essentially necessary conditions or Minute Technique. The scientific classification for the examination strategies are appeared in the Figure 2.

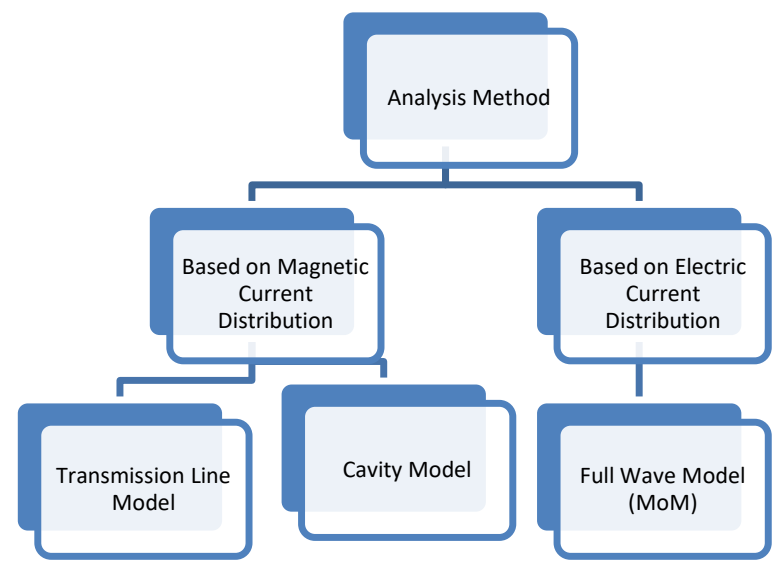

Figure 2: Analysis methods for the microstrip antenna In general, the transmission line show is the least complex of all strategy utilized and it gives great physical perception yet it is moderately less precise when contrasted with other model utilized. The cavity display is progressively exact and gives great physical perception too yet it is moderately mind boggling to design. The full wave models, for example, the Technique for Minutes is much versatile, very precise, and can treat single components, stacked components, finite arrays and limitless clusters, even subjective molded components and coupling. These characters give less physical understanding when contrasted with the two models referenced above and it is unquestionably increasingly complex in nature. In the following areas, the three techniques referenced above are talked about quickly.

\section{CONCLUSION}

In this paper, it is at first displayed the essential parameters of the antenna is discussed while planning an antenna and deciding the working frequency groups. In the middle, previous research work is discuses. The new microstrip patch antenna array is discussed at $6 \mathrm{GHz}$ frequency range. CST software can be used for design antenna array. 


\section{REFERENCE}

[1] A. N'Gom, A. Diallo, J. M. Ribero and A. C. Beye, "Design of an adaptive subarray antenna for multibeams wireless small cell backhaul in mmWave," 2018 IEEE Conference on Antenna Measurements \& Applications (CAMA), Vasteras, 2018, pp. 1-4.

[2] J. Lin, W. Xu, J. Wang and H. Zhang, "A Novel Dual-Band Magneto-Electric Dipole End-Fire Antenna," 2018 IEEE 18th International Conference on Communication Technology (ICCT), Chongqing, 2018, pp. 552-555.

[3] Y. N. Wijayanto, A. Kanno, H. Murata, T. Kawanishi and P. Adhi, "W-band millimeter-wave patch antennas on optical modulator for runway security systems," 2017 IEEE Conference on Antenna Measurements \& Applications (CAMA), Tsukuba, 2017, pp. 79-82.

[4] M. Sugadev and E. Logashanmugam, "A compact multiple slot microstrip antenna for modern mobile communications," 2016 International Conference on Control, Instrumentation, Communication and Computational Technologies (ICCICCT), Kumaracoil, 2016, pp. 805-808.

[5] A. Abdellatif, M. Ghassemi, M. Nezhad-Ahmadi, S. SafaviNaeini and N. Ghassemi, "Low cost low loss waveguide-fed patch antenna array for automotive radar system," Global Symposium on Millimeter-Waves (GSMM), Montreal, QC, 2015, pp. 1-3.

[6] Bin Lu, Jun Luo, Lei Zhang, Li Zhang, Ruifeng Yue and Yan Wang, "A patch antenna array for $60-\mathrm{GHz}$ WPAN based on polypropylene composite substrate," 2014 IEEE International Conference on Electron Devices and Solid-State Circuits, Chengdu, 2014, pp. 1-2.

[7] R. J. Chitra, M. Rajasekaran and V. Nagarajan, "Design of double L-slot microstrip patch antenna array for WiMAX/WLAN application using step width junction feed," 2013 International Conference on Communication and Signal Processing, Melmaruvathur, 2013, pp. 298-304.

[8] S. Muhamud, M. T. Ali and M. K. M. Salleh, "An aperture coupled microstrip antenna (ACMSA) with orientations of patch slot," 2012 Asia-Pacific Symposium on Electromagnetic Compatibility, Singapore, 2012, pp. 913-916.

[9] S. M. R. Razavizadeh, "A dual band circular-shaped patch array antenna for WLAN/WiMAX access-point applications," 2011 IEEE International Symposium on Antennas and Propagation (APSURSI), Spokane, WA, 2011, pp. 1342-1345.

[10] M.N. Srifi, M. Meloui and M. Essaaidi, "Rectangular slotted patch antenna for 5-6GHz applications," International Journal of Microwave and Optical Technology, vol. 5, no. 2, March 2010, pp.52-57. 